Research Paper

\title{
Potential synergistic effect of phosphodiesterase inhibitors with chemotherapy in lung cancer
}

\author{
Kalliopi Domvri ${ }^{1}$, Konstantinos Zarogoulidis ${ }^{1}$, Nikolaos Zogas ${ }^{3}$, Paul Zarogoulidis ${ }^{\bowtie}{ }^{\bowtie}$, Savvas Petanidis ${ }^{4}$, \\ Konstantinos Porpodis ${ }^{1}$, Efrosini Kioseoglou ${ }^{3}$, Wolfgang Hohenforst-Schmidt ${ }^{2}$ \\ 1. Pulmonary Department-Oncology Unit, "G. Papanikolaou" General Hospital, Aristotle University of Thessaloniki, Thessaloniki, Greece \\ 2. Sana Clinic Group Franken, Department of Cardiology / Pulmonology / Intensive Care / Nephrology, "Hof" Clinics, University of Erlangen, \\ Hof, Germany \\ 3. Gene and Cell Therapy Center, Hematology Department-Bone Marrow Transplantation Unit, “G. Papanikolaou” General Hospital, Thessaloniki, Greece \\ 4. Department of Chemical Engineering, Aristotle University of Thessaloniki, Thessaloniki, Greece \\ $\triangle$ Corresponding author: Paul Zarogoulidis, M.D, Ph. D; Pulmonary Department-Oncology Unit, "G. Papanikolaou” General Hospital, Aristotle University of \\ Thessaloniki, Thessaloniki, Greece. Fax: 00302310992424; Mobile: 00306977271974; E-mail: pzarog@hotmail.com \\ (c) Ivyspring International Publisher. This is an open access article distributed under the terms of the Creative Commons Attribution (CC BY-NC) license \\ (https://creativecommons.org/licenses/by-nc/4.0/). See http://ivyspring.com/terms for full terms and conditions.
}

Received: 2017.07.05; Accepted: 2017.08.08; Published: 2017.10.09

\begin{abstract}
Purpose: Lung cancer remains the leading cause of cancer-related deaths worldwide and novel therapeutic approaches targeting crucial pathways are urgently needed to improve its treatment. Differentiation-based therapeutics (Methylxanthines) and phosphodiesterase inhibitors (type 4 and 5), have been implicated in cancer treatment. Our objectives were to capture any potential anti-tumor effect of these drug combinations with chemotherapeutic agents in vitro.

Methods: Theophylline as Methylxanthines, Roflumilast as phosphodiesterase type 4 (PDE4) inhibitor and Sildenafil as phosphodiesterase type 5 (PDE5) inhibitor are the drugs that we combined with the chemotherapeutic agents (Docetaxel, Cisplatin and Carboplatin) in vitro. Lung cancer cell lines (NCl-H1048-Small cell lung cancer-SCLC, A549- Non-small cell lung cancer-NSCLC) were purchased from ATCC LGC Standards. At indicated time-point, following $24 \mathrm{~h}$ and $48 \mathrm{~h}$ incubation, cell viability and apoptosis were measured with Annexin $\mathrm{V}$ staining by flow cytometry. Statistical analysis was performed by GraphPad Prism.

Results: In SCLC, following 48h incubation, platinum combinations of carboplatin with roflumilast and sildenafil $(p<0.001)$ and carboplatin with theophylline and sildenafil showed increased apoptosis when compared to carboplatin alone. Concerning the combinations of cisplatin, when combined with roflumilast, theophylline and sildenafil appeared with increased apoptosis of that alone ( $p<0.001,24 \mathrm{~h}$ and $48 \mathrm{~h}$ incubation). In NSCLC, the $24 \mathrm{~h}$ incubation was not enough to induce satisfactory apoptosis, except for the combination of cisplatin with roflumilast and theophylline $(\mathrm{p}<0.05)$ when compared to cisplatin alone. However, following $48 \mathrm{~h}$ incubation, carboplatin plus sildenafil, carboplatin plus sildenafil, theophylline and roflumilast showed more cytotoxicity when compared to carboplatin alone $(p<0.001)$. Docetaxel combinations showed no statistically significant results.
\end{abstract}

Conclusion: The synergistic effect of PDE inhibitors with platinum-based agents has been demonstrated in lung cancer. Our suggestion is that these combinations could be used as additive and maintenance treatment in combination to antineoplastic agents in lung cancer patients.

Key words: lung cancer, theophylline, roflumilast, sildenafil, cisplatin, carboplatin, synergistic effect

\section{Introduction}

Lung cancer is still the most common type of cancer and the leading cause of cancer-related deaths worldwide.[1-3]. Lung cancer is subdivided into two histological groups: Small Cell Lung Cancer (SCLC) 
and Non-Small Cell lung Cancers (NSCLC) which accounts for almost $85 \%$ of all lung cancers.[4] Platinum-etoposide combination combined with thoracic and prophylactic cranial irradiation has been shown to improve outcome in limited-stage SCLC (TxNxM0) and in subgroups of extensive-stage SCLC $(\mathrm{Tx}, \mathrm{Nx}, \mathrm{M} 1 \mathrm{a} / \mathrm{b})$, however, the clinical outcome for SCLC remains still discouraging.[5] Similarly, classical chemotherapy (platinum-doublet, taxanes, gemcitabine, pemetrexed) results in modest efficacy in NSCLC. At this point, the identification of molecular biomarkers such as EGFR inhibitors, have led to personalized therapy in NSCLC, but mechanisms of resistance remain to be elucidated.[6] Novel therapeutic approaches targeting crucial pathways are urgently needed to improve the treatment of lung cancer. Regarding neuroendocrine tumors with $\mathrm{Ki}-67 \leq 20 \%$ the formulation everolimus can be used.[7]

The aim of the multidrug therapy is a crucial treating option for lung cancer, though in several studies, multimodal therapeutic strategy resulted in superior efficacy, but at the expense of added toxicity.[8] [9] The success of multidrug therapy is based on acting simultaneously on different disease hallmarks.

Promising agents with antitumor action include cyclic nucleotide phosphodiesterase enzymes (PDEs) which are a large superfamily of enzymes that catalyze the hydrolytic breakdown of cyclic nucleotides cyclic adenosine monophosphate (cAMP) and cyclic guanosine monophosphate (cGMP) that regulate various biological processes such as cell growth, energy homeostasis, muscle relaxation, and neuronal signaling.[10] Specifically, PDE-5, -6 , and -9 are selective for cGMP and PDE- $4,-7$, and -8 are cAMP selective, whereas PDE-1, $-2,-3,-10$, and -11 are dual substrate-degrading isozymes.[11] According to several studies in various carcinomas such as breast cancers, colon adenocarcinoma, bladder squamous carcinoma, and lung cancers, it has been implied that PDEs may have antineoplastic effects by significantly lower cGMP levels than normal cells and may increase the specificity of a given chemotherapeutic agent.[1, 10, 12-15]

Roflumilast is the only PDE-4 inhibitor approved by the US Food and Drug Administration that targets inflammatory cells involved in triggering exacerbations of COPD.[16] It is catalyzed by cytochrome P450 1A2 and 3A4 to its active metabolite, roflumilast $\mathrm{N}$-oxide, which is responsible for $>90 \%$ of the total PDE-4 inhibitory activity of roflumilast.[17] Recently, it has been reported that roflumilast in the treatment of B-cell malignancies suppresses the activity of the oncogenic PI3K/AKT kinases, and might have clinical activity in this setting.[18] In the same superfamily belongs Sildenafil, a PDE-5 inhibitor, which is used clinically for treating erectile dysfunction (ED) and pulmonary hypertension. Recently, sildenafil has shown to induce apoptosis in human tumors, such as colon carcinoma and chronic lymphocyte leukemia.[19, 20] Furthermore, PED5 expression has been shown to be increased on various cancers including breast, colon, bladder and lung cancer.[21-24] Besides sildenafil, other PED5 inhibitors are vardenafil and tadalafil.

Methylxanthines (MXs) are nonselective phosphodiesterase inhibitors, obtained from natural sources, contained in beverages (coffee, tea, etc.), whereas others have been used as therapeutic agents, and recently have been marked differentiative properties on tumor cells. $[25,26]$ The best known of these natural alkaloids are theophylline (TH, 1,3-dimethylxanthine), theobromine (3,7-dimethylxanthine), aminophylline (1,3-dimethyl-7Hpurine-2,6-dione) and caffeine (1,3,7-trimethylxanthine). Theophylline, also known as 1,3-dimethylxanthine is being used as a bronchodilator drug in pulmonary diseases such as asthma or chronic pulmonary obstructive disease (COPD).[25, 27, 28] The main role of theophylline is acting as a non-specific adenosine antagonist, antagonizing A1, A2 and A3 receptors almost equally.[3] Investigated activities of theophylline derivatives, 7- and 8-positions include bronchospasmolytic[29, 30] anticancer, antimicrobial and circulatory blood system activity.[31] Concerning the antiproliferative and antimetastatic activities of $\mathrm{TH}$, it has been reported to have beneficial effects alone or in combination with chlorambucil, in leukemia patients.[32, 33] Furthermore, TH was reported to negatively affect melanoma cell invasiveness in vitro and in vivo and to induce tumor cell differentiation through transglutaminase (TG, EC 2.3.2.13) activation.[34-36]

Taken together, these data have demonstrated a potential use of differentiation-based therapeutics such as Methylxanthines and phosphodiesterase inhibitors in cancer proliferation and apoptosis. In this study, we investigated the cytotoxicity of combined treatment of theophylline, roflumilast and sildenafil with platinum analogs or docetaxel on SCLC and NSCLC in vitro.

\section{Materials and Methods}

\section{Cell cultures and reagents}

The small cell lung cancer cell line [NCI-H1048 [H1048], ATCC ${ }^{\circledR}$ CRL-5853 ${ }^{\mathrm{TM}}$ ) was purchased from ATCC LGC Standards. NCI-H1048 cells were cultured 
in ATCC-formulated Dulbecco's Modified Eagle's Medium (DMEM):F12 Medium culture medium, supplemented with 5\% Fetal Bovine Serum (FBS) and with the following components, $0.005 \mathrm{mg} / \mathrm{ml}$ Insulin, $0.01 \mathrm{mg} / \mathrm{ml}$ Transferrin, 30nM Sodium selenite (final conc.), $10 \mathrm{nM}$ Hydrocortisone (final conc.), $10 \mathrm{nM}$ beta-estradiol (final conc.), extra $2 \mathrm{mM}$ L-glutamine (for final conc. of $4.5 \mathrm{mM}$ ), 5\% fetal bovine serum (final conc.), all purchased from SIGMA. The non-small cell lung cancer cell line (A549, ATCC ${ }^{\circledR}$ CCL185 ${ }^{\mathrm{TM}}$ ) was also purchased from ATCC LGC Standards. A549 cell line was cultured in DMEM, supplemented with 5\% FBS, $1 \mathrm{mM}$ Penicillin-Streptomycin and $2 \mathrm{mM}$ L-glutamine, all purchased from SIGMA.

Lung cancer cell lines were incubated at $37^{\circ} \mathrm{C}$ in a humidified atmosphere containing $5 \% \mathrm{CO}_{2}$ [37] and cultured in Coming's tissue culture flasks (25 and 75 $\mathrm{cm}^{2}$ ) according to the manufacturer's protocol. After cultures reached confluence, by microscope observation were then subcultured. Cells were detached with trypsin (1:250) $2.5 \%$ and passaged. The indicated cell lines were seeded in $25 \mathrm{~cm}^{2}$ flasks $0.7 \times$ $10^{6}$ cells at a seeding density of $10^{6}$ cells for each cell. At confluence, at indicated time point, test compounds were added according to our protocol and after $24 \mathrm{~h}$ or $48 \mathrm{~h}$ incubation apoptosis was measured (Table 1).

Table 1. Protocol of the experiment

Incubation of the drugs in lung cancer cell lines

1. Addition of chemotherapeutic agents alone for $2 \mathrm{~h}$

2. Addition of PDE inhibitors alone for $2 \mathrm{~h}$

3. Addition of combinations for $2 \mathrm{~h}$ : chemotherapeutic agents $(25 \mu \mathrm{M})+$ PDE inhibitors $(100 \mu \mathrm{M})$ as follows: (sildenafil alone, roflumilast alone, theophylline alone, sildenafil + roflumilast, sildenafil + theophylline, roflumilast + theophylline, sildenafil + roflumilast + theophylline)

4. After $24 \mathrm{~h}$ and $48 \mathrm{~h}$ incubation, apoptosis was measured

\section{Test compounds}

Drugs used in this study, include roflumilast (DAXAS® 500mg) as PED-4 inhibitor, sildenafil (Viagra ${ }^{\circledR} 50 \mathrm{mg}$ ) as PED-5 inhibitor and theophylline as methylaxines. These compounds were tested at concentration of $100 \mu \mathrm{M}$. Docetaxel $(10 \mathrm{mg} / \mathrm{ml}$, $140 \mathrm{mg} / 5.5 \mathrm{~L})$, Carboplatin $(10 \mathrm{mg} / \mathrm{ml}, 350 \mathrm{mg} / 5.5 \mathrm{~L})$ and Cisplatin $(1 \mathrm{mg} / \mathrm{ml}, 90 \mathrm{mg} / 5.5 \mathrm{~L})$ at concentration of $25 \mu \mathrm{M}$ are the chemotherapeutic agents that we combined with PDE inhibitors. All combinations were tested in triplicate (Table 1 ).

\section{Analysis of the apoptotic cells with ANNEXIN VI PI}

Annexin V staining is used as a probe to detect cells that have expressed phosphatidylserine (PS) on the cell surface, an event found in apoptosis as well as other forms of cell death. Propidium iodide (PI) is used as a DNA stain for both flow cytometry, to evaluate cell viability or DNA content in cell cycle analysis 17 , and microscopy to visualize the nucleus and other DNA containing organelles. It can be used to differentiate necrotic, apoptotic and normal cells. The Annexin V kit used in this study was purchased from Immunostep (Salamanca, Spain). Data were acquired on a FACS Calibur (BD, Franklin Lakes, NJ, USA) instrument, and analyzed using the CellQuest Pro v6 software (BD) or FlowJo software vX.0.7 (Tree Star).

\section{Statistical analysis}

Data are presented as means \pm standard error of the mean (SEM). Multiple comparisons between experimental groups for one or more variables were performed using one- or two-way ANOVA, respectively, with Tukey's post-hoc test. Values of $p \leq 0.05$ were considered as statistically significant. All the analyses were undertaken using PRISM version 6.01 (GraphPad software, version 6, San Diego, CA. USA).

\section{Results}

In Small cell lung cancer cells, following $48 \mathrm{~h}$ incubation, combinations of carboplatin with roflumilast and sildenafil $(\mathrm{p}<0.001)$ and carboplatin with theophylline 3 and sildenafil showed increased apoptosis when compared to carboplatin alone (Table 3, Figure 1). Concerning the combinations of cisplatin, when combined with roflumilast, theophylline and sildenafil appeared with increased apoptosis of that alone $(p<0.001)$. In SCLC, the only combination that showed increased apoptosis following $24 \mathrm{~h}$ incubation was cisplatin combined with roflumilast, theophylline and sildenafil that resulted in increased apoptosis when compared with cisplatin alone $(\mathrm{p}<0.001)$ (Table 2 , Figure 2). In Non-small cell lung cancer cells, the $24 \mathrm{~h}$ incubation was not enough to induce satisfactory apoptosis, except for the combination of cisplatin with roflumilast and theophylline $(\mathrm{p}<0.05)$ when compared to cisplatin alone (Table 4, Figure 4). However, following $48 \mathrm{~h}$ incubation, carboplatin plus sildenafil, carboplatin plus sildenafil, theophylline and roflumilast showed more cytotoxicity when compared to carboplatin alone $(\mathrm{p}<0.001)$ (Table 5, Figure 3). Docetaxel combinations with PDE inhibitors showed no statistically significant cytotoxicity when compared to them alone.

\section{Discussion}

Nowadays, novel combined chemotherapeutic treatments have led to a continuous improvement on 
long-term survival and quality of life in patients in various cancers. However, new strategies are at need due to deleterious side effects and drug resistance obvious as poor efficacy for late stages of disease. More specifically, platinum containing drugs combined with other agents are used to treat a variety of cancer cell types, including lung cancer, as standard of care, showing significant effectiveness. Resistance to platinum-based drugs is a fact, affecting the efficacy and prognosis. The mechanisms of drug resistance are complicated, due to a variety of etiologies among others, such as abnormal expressions of membrane proteins, enhanced DNA repair functions, abnormal regulation mechanisms of apoptosis, and enhanced cellular detoxification function.[38]

The present study was designed to determine whether the addition of PDE inhibitors interacted with standard of care platinum-based chemotherapeutic agents to kill lung cancer cells in vitro. Our data show that in both lung cancer cell lines, platinum combinations with PDE inhibitors showed increased antiproliferative effect on lung cancer cell lines when compared to platinum monotherapy. In specific, the addition of sildenafil alone with cisplatin or carboplatin or with other PDE inhibitors (roflumilast and/or theophylline) combined, increased apoptosis in lung cancer cell lines. Cytotoxic effect of cisplatin exerts via the formation of mono-, inter-, and intra-strand cisplatin-DNA adducts, which can ultimately result in cell cycle arrest in G1, S, or G2-M phases [39-41] and induction of apoptosis.[42, 43] As for PDE-5 inhibitors, studies have reported that increase intracellular cGMP levels via their inhibition on cGMP-specific PDE5 [44, 45], suggesting that may be

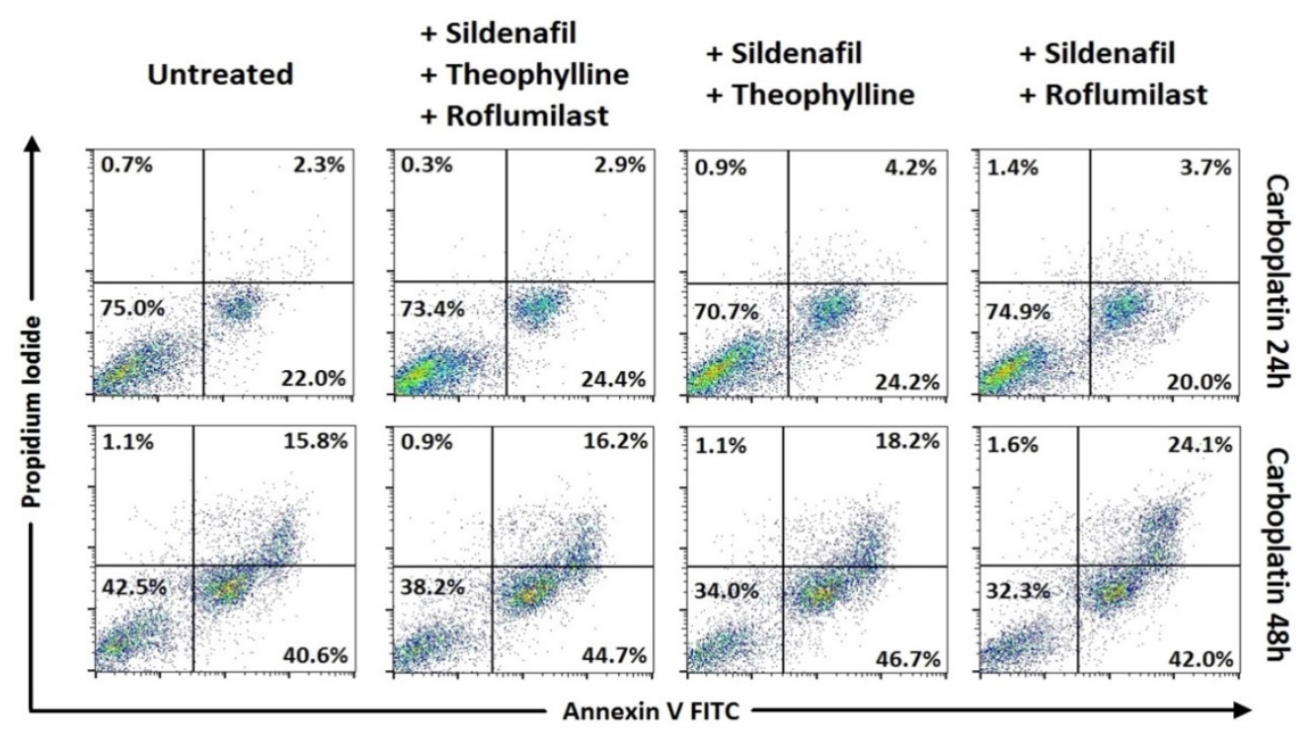

Figure 1. Cell viability and apoptosis with Annexin V/Propidium iodide by flow cytometry. Representative data for SCLC. Combinations of phosphodiesterase inhibitors with carboplatin, with statistically significant differences. effective pharmacological modulators in the cGMP pathway which has the map to enhance drug delivery to tumor tissues. Recently, $\mathrm{Li}$ et al demonstrated that PDE5 inhibition enhanced cytotoxicity likely due to the increase of drug uptake via endocytosis[46], suggesting it as adjuvant therapy for lung cancer. Besides, it has been reported that PDE5 inhibitors are overexpressed in many tumors, including lung, colon, breast, bladder, prostate and leukemia.[13, 47, 48] In the future we try and make a stratification with the expression of ki-67 in neuroendocrine tumors and the association with the efficacy of the drugs that we tested. Regarding the neuroendocrine tumors the ki-67 percentage plays a crucial role for treatment that should be followed. Nowadays if the percentage of the ki-67 is $\leq 20 \%$ treatment with the pill everolimus can be provided, in the case of $\geq 21$ then chemotherapy should be provided and when necessary along with radiotherapy.[7]

Furthermore, several studies have demonstrated that sildenafil showed antitumor activity in mouse models [49-52] and that PDE5 inhibition resulted in growth inhibition of tumor cells in vitro particularly by enhancing anticancer drugs.[20, 53-61] Also, sildenafil has been suggested as useful in mitigating the nephrotoxicity of cisplatin in rats.[2] in enhancing the efficacy of anticancer drugs comes from the inhibition of ABCB1 (P-glycoprotein/P-gp) and ABCG2 (Breast Cancer Resistance Protein/BCRP). $[62,63]$ However, another study by Lin et al that performed an experiment on wild-type and $\mathrm{ABCB} 1 ; \mathrm{BCG} 2$ knockout mice to assess the potency and usefulness of sildenafil showed insufficient results for further clinical testing.[64]

http://www.jcancer.org
Other studies suggested that the role of sildenafil 


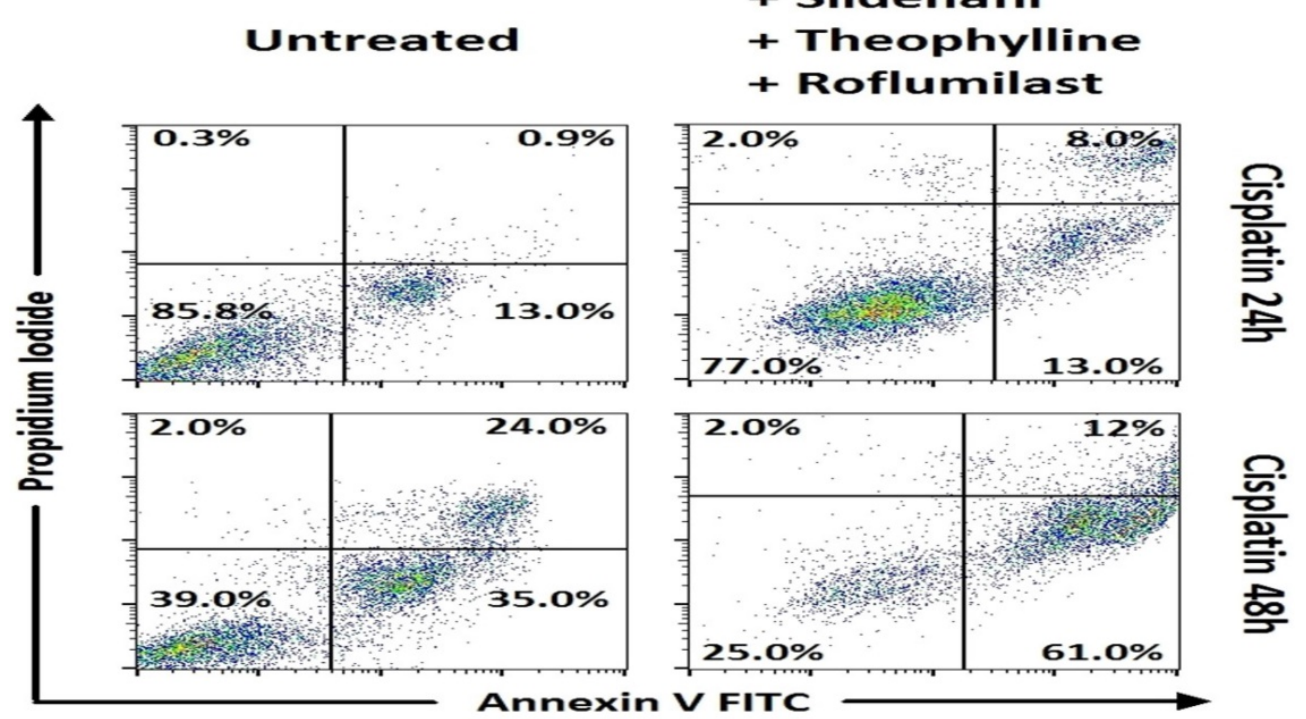

Figure 2. Cell viability and apoptosis with Annexin V/Propidium iodide by flow cytometry. Representative data for SCLC. Combinations of phosphodiesterase inhibitors with cisplatin, with statistically significant differences.

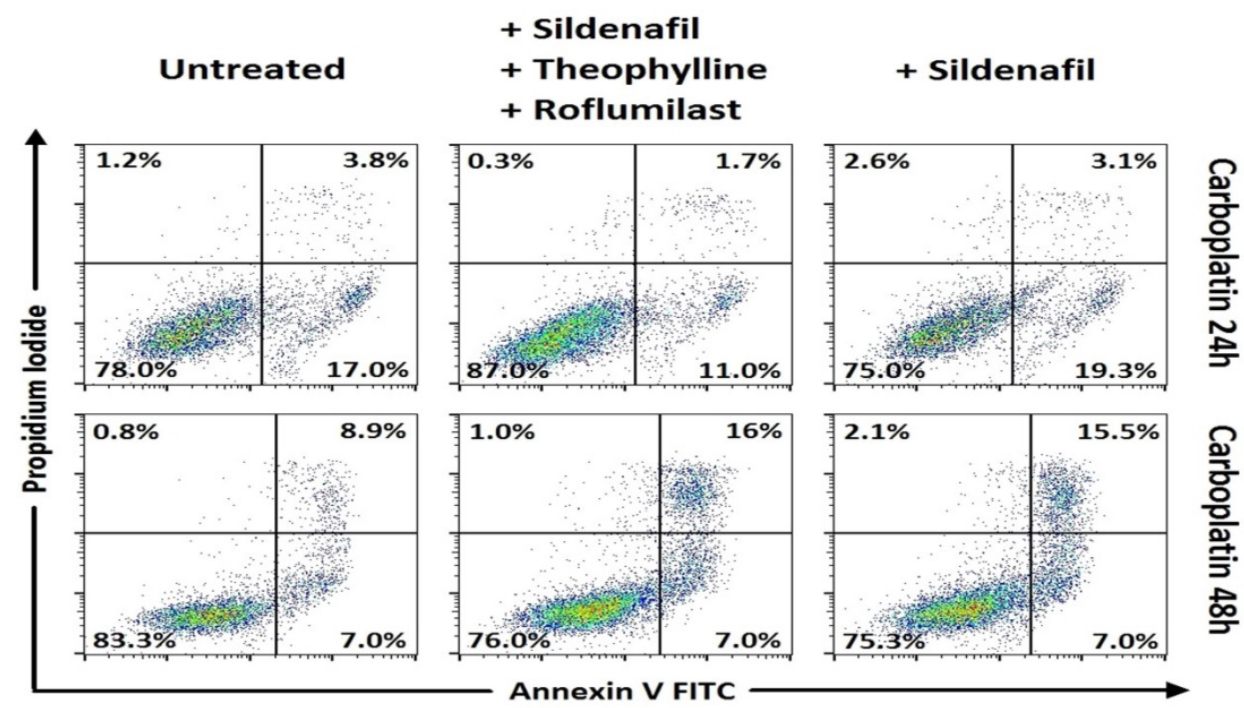

Figure 3. Cell viability and apoptosis with Annexin V/Propidium iodide by flow cytometry. Representative data for NSCLC. Combinations of phosphodiesterase inhibitors with carboplatin, with statistically significant differences.

In addition, there are studies that have reported a concern about using PDE inhibitors. Based on evidence linking the use of PDE with increased risk of melanoma supported by recent studies [65-69], Pottegard et al conducted two parallel case-control studies, using the Danish Nationwide Health Registries (DNHR) and the Kaiser Permanente Northern California (KPNC) electronic health records, concluding to little evidence for a causal association between PDE inhibitors use and risk of melanoma.[70]

To our knowledge, this is the first report to combine various PDE inhibitors with chemotherapy in lung cancer cell lines. In our study, the addition of sildenafil plus theophylline with or without roflumilast combined with carboplatin or cisplatin showed increased apoptosis when compared with platinum-based drugs alone. Despite the high pharmacological doses [71] and questionable protective effect against cisplatin nephrotoxicity [72], theophylline has been proposed as a potential anti-cancer drug combined with chemotherapeutic regimens for more than a decade.[36, 43, 73, 74] Specifically, the synergistic effect of theophylline with chemotherapeutic drugs comes from the induction of apoptosis and the interference with the cell cycle.[73] As for roflumilast, a number of publications have suggested the antitumor activity of this PDE4 inhibitor.[18, 75-77] According to researchers its anticancer action is related to its ability to influence glucocorticoid (GC) sensitivity in the malignant lymphocyte.[78] 
Untreated

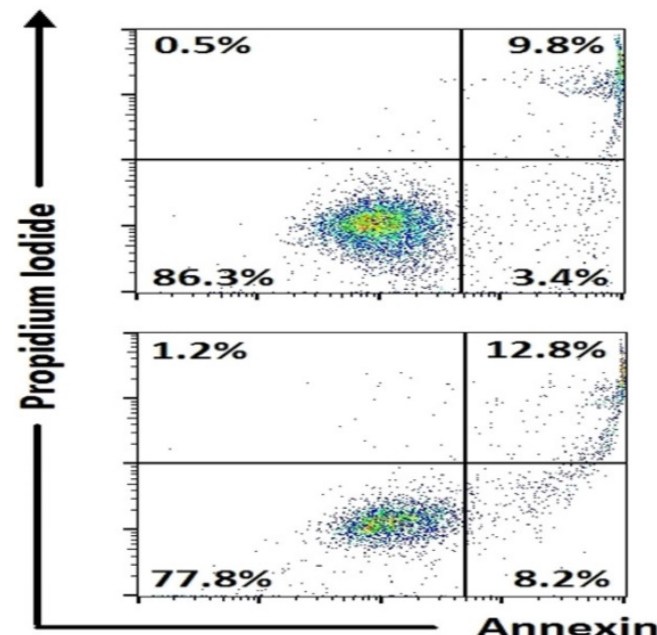

+ Theophylline

+ Roflumilast
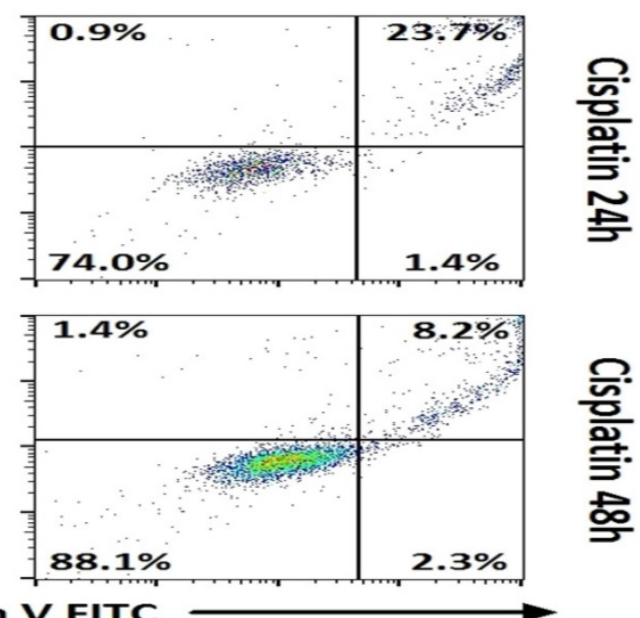

Figure 4. Cell viability and apoptosis with Annexin V/Propidium iodide by flow cytometry. Representative data for NSCLC. Combinations of phosphodiesterase inhibitors with cisplatin, with statistically significant differences.

Table 2. Means \pm standard error of the mean (SEM) of percentages for cell viability and apoptosis with Annexin V/ Propidium iodide by flow cytometry in SCLC cancer cell lines after $24 \mathrm{~h}$ incubation with drugs (representative data).

\begin{tabular}{|c|c|c|c|c|}
\hline $\begin{array}{l}\text { Drug } \\
\text { combinations }\end{array}$ & Dead \% & $\begin{array}{l}\text { Late Apoptotic } \\
\%\end{array}$ & $\begin{array}{l}\text { Early } \\
\text { Apoptotic \% }\end{array}$ & Live \% \\
\hline $\begin{array}{l}\text { Untreated cells } \\
\text { SCLC }\end{array}$ & $2.6 \pm 1.5$ & $7.7 \pm 1.5$ & $4.3 \pm 1.4$ & $86.9 \pm 3.5$ \\
\hline Carboplatin & $1.7 \pm 3$ & $2 \pm 2.5$ & $21 \pm 1.5$ & $74.5 \pm 3$ \\
\hline $\begin{array}{l}\text { Carboplatin + } \\
\text { sildenafil + } \\
\text { theophylline + } \\
\text { roflumilast }\end{array}$ & $1.3 \pm 1$ & $3 \pm 3$ & $23 \pm 2$ & $71.4 \pm 3.2$ \\
\hline $\begin{array}{l}\text { Carboplatin + } \\
\text { theophylline + } \\
\text { sildenafil }\end{array}$ & $1.6 \pm 1$ & $4 \pm 2.3$ & $23 \pm 1$ & $71.1 \pm 3$ \\
\hline $\begin{array}{l}\text { Carboplatin + } \\
\text { roflumilast + } \\
\text { sildenafil }\end{array}$ & $1 \pm 0.5$ & $4 \pm 2$ & $21 \pm 2.5$ & $75.4 \pm 2.1$ \\
\hline Cisplatin & $1.3 \pm 2$ & $1 \pm 1.5$ & $12 \pm 3$ & $85 \pm 2$ \\
\hline $\begin{array}{l}\text { Cisplatin + } \\
\text { sildenafil } \\
\text { theophylline + } \\
\text { roflumilast }\end{array}$ & $1.5 \pm 1$ & $7.7 \pm 1.2$ & $14 \pm 2.1$ & $76 \pm 2.8$ \\
\hline
\end{tabular}

Besides platinum-based regimens, in our study, we combined docetaxel with the same PDE inhibitors (sildenafil, rofumilast, theophylline). However, we found no significant differences when compared to docetaxel monotherapy. This chemotherapeutic drugs stop mitosis in the M phase of the cell cycle, whereas platinum analogs are cell cycle non-specific agents.[40]

In conclusion, although the synergistic effect is documented, the benefit of PDE inhibitors on chemotherapy may be dependent on cancer types and chemotherapeutics. Further laboratory research and clinical studies are required to fully understand the mechanisms of drug interaction and clinical utility of this therapeutic approach. We argue that the next step for our research could be to propose a phase I trial of these combinations to determine safe doses of the PDE inhibitors combinations to be followed by phase II trials in conjunction with platinum, in patients who have displayed platinum resistance. This perhaps would show the ability of these combinations to re-sensitize tumors to platinum and at the same time suggesting lower doses of chemotherapeutic drugs.

Table 3. Means \pm standard error of the mean (SEM) of percentages for cell viability and apoptosis with Annexin V/ Propidium iodide by flow cytometry in SCLC cancer cell line after $48 \mathrm{~h}$ incubation with drugs (representative data).

\begin{tabular}{|c|c|c|c|c|}
\hline $\begin{array}{l}\text { Drug } \\
\text { combinations }\end{array}$ & Dead \% & $\begin{array}{l}\text { Late Apoptotic } \\
\%\end{array}$ & $\begin{array}{l}\text { Early } \\
\text { Apoptotic \% }\end{array}$ & Live \% \\
\hline $\begin{array}{l}\text { Untreated cells } \\
\text { SCLC }\end{array}$ & $1.5 \pm 1$ & $3.9 \pm 1.3$ & $4.2 \pm 1$ & $90 \pm 3.2$ \\
\hline Carboplatin & $1 \pm 1.2$ & $16 \pm 1.5$ & $41 \pm 2$ & $43 \pm 3.2$ \\
\hline $\begin{array}{l}\text { Carboplatin + } \\
\text { sildenafil + } \\
\text { theophylline + } \\
\text { roflumilast }\end{array}$ & $1 \pm 1$ & $16 \pm 2.8$ & $45 \pm 3.5$ & $40 \pm 3$ \\
\hline $\begin{array}{l}\text { Carboplatin + } \\
\text { theophylline + } \\
\text { sildenafil }\end{array}$ & $1.4 \pm 1.1$ & $18 \pm 2$ & $47 \pm 1.6$ & $35 \pm 2.2$ \\
\hline $\begin{array}{l}\text { Carboplatin + } \\
\text { roflumilast + } \\
\text { sildenafil }\end{array}$ & $2 \pm 0.9$ & $25 \pm 4$ & $41 \pm 1.1$ & $33 \pm 2.8$ \\
\hline Cisplatin & $2.4 \pm 1.1$ & $23.5 \pm 2.5$ & $36 \pm 3$ & $38 \pm 2.1$ \\
\hline $\begin{array}{l}\text { Cisplatin + } \\
\text { sildenafil } \\
\text { theophylline + } \\
\text { roflumilast }\end{array}$ & $1.8 \pm 1.1$ & $10.5 \pm 2$ & $62 \pm 2.2$ & $25.4 \pm 2.9$ \\
\hline
\end{tabular}


Table 4. Means \pm standard error of the mean (SEM) of percentages for cell viability and apoptosis with Annexin V/ Propidium iodide by flow cytometry in NSCLC cancer cell line after $24 \mathrm{~h}$ incubation with drugs (representative data).

\begin{tabular}{|c|c|c|c|c|}
\hline $\begin{array}{l}\text { Drug } \\
\text { combinations }\end{array}$ & Dead \% & $\begin{array}{l}\text { Late Apoptotic } \\
\%\end{array}$ & $\begin{array}{l}\text { Early Apoptotic } \\
\%\end{array}$ & Live $\%$ \\
\hline $\begin{array}{l}\text { Untreated cells } \\
\text { NSCLC }\end{array}$ & $0.5 \pm 0.6$ & $5.5 \pm 1.4$ & $1.8 \pm 1$ & $92 \pm 3.3$ \\
\hline Carboplatin & $2 \pm 1.1$ & $3 \pm 1$ & $16 \pm 2.2$ & $79 \pm 3$ \\
\hline $\begin{array}{l}\text { Carboplatin + } \\
\text { sildenafil + } \\
\text { theophylline + } \\
\text { roflumilast }\end{array}$ & $1 \pm 0.8$ & $1.5 \pm 1$ & $12 \pm 2$ & $86 \pm 3.1$ \\
\hline $\begin{array}{l}\text { Carboplatin + } \\
\text { sildenafil }\end{array}$ & $2.6 \pm 1.2$ & $3 \pm 1.5$ & $19 \pm 1.7$ & $75 \pm 2.8$ \\
\hline Cisplatin & $0.5 \pm 0.8$ & $9 \pm 1.5$ & $3 \pm 1.4$ & $88 \pm 3$ \\
\hline $\begin{array}{l}\text { Cisplatin + } \\
\text { theophylline + } \\
\text { roflumilast }\end{array}$ & $0.5 \pm 1.1$ & $24 \pm 4$ & $1 \pm 2$ & $75 \pm 3.5$ \\
\hline
\end{tabular}

Table 5. Means \pm standard error of the mean (SEM) of percentages for cell viability and apoptosis with Annexin V/ Propidium iodide by flow cytometry in NSCLC cancer cell line after $48 \mathrm{~h}$ incubation with drugs (representative data).

\begin{tabular}{|c|c|c|c|c|}
\hline $\begin{array}{l}\text { Drug } \\
\text { combinations }\end{array}$ & Dead \% & $\begin{array}{l}\text { Late Apoptotic } \\
\%\end{array}$ & $\begin{array}{l}\text { Early Apoptotic } \\
\%\end{array}$ & Live \% \\
\hline $\begin{array}{l}\text { Untreated cells } \\
\text { NSCLC }\end{array}$ & $0.5 \pm 0.6$ & $5.5 \pm 1.4$ & $1.8 \pm 1$ & $92 \pm 3.3$ \\
\hline Carboplatin & $0.9 \pm 1$ & $8.9 \pm 2$ & $7 \pm 1.9$ & $83 \pm 3.1$ \\
\hline $\begin{array}{l}\text { Carboplatin + } \\
\text { sildenafil + } \\
\text { theophylline + } \\
\text { roflumilast }\end{array}$ & $1.1 \pm 0.5$ & $17 \pm 1.3$ & $6.5 \pm 2$ & $75 \pm 3.3$ \\
\hline $\begin{array}{l}\text { Carboplatin + } \\
\text { sildenafil }\end{array}$ & $2 \pm 1$ & $15 \pm 2.5$ & $7.3 \pm 2.3$ & $75 \pm 2.6$ \\
\hline Cisplatin & $0.5 \pm 0.9$ & $11 \pm 2.5$ & $10 \pm 2.3$ & $79 \pm 2.5$ \\
\hline $\begin{array}{l}\text { Cisplatin + } \\
\text { theophylline + } \\
\text { roflumilast }\end{array}$ & $0.8 \pm 0.9$ & $7 \pm 1.9$ & $2 \pm 0.8$ & $91 \pm 3$ \\
\hline
\end{tabular}

\section{Acknowledgements}

The abstract of this paper was presented at the $23^{\text {rd }}$ Panhellenic Congress that took place in Thessaloniki, Greece. It was presented as poster with the following authorship/information: AB063. Potential synergistic effect by combination of PED-4 and PED-5 inhibitors plus theophylline in lung cancer? Ann Transl Med. 2016 Nov; 4(22): AB063. doi: 10.21037/atm.2016.AB063 nlm.nih.gov/pmc/articles/PMC5159351/

\section{Competing Interests}

The authors have declared that no competing interest exists.

\section{References}

1. Abadi AH, Abouel-Ella DA, Ahmed NS, Gary BD, Thaiparambil JT, Tinsley $\mathrm{HN}$, et al. Synthesis of novel tadalafil analogues and their evaluation as phosphodiesterase inhibitors and anticancer agents. Arzneimittel-Forschung. 2009; 59: 415-21.

2. Ali BH, Abdelrahman AM, Al-Salam S, Sudhadevi M, AlMahruqi AS, Al-Husseni IS, et al. The effect of sildenafil on cisplatin nephrotoxicity in rats. Basic \& clinical pharmacology \& toxicology. 2011; 109: 300-8. doi:10.1111/j.1742-7843.2011.00724.x.

3. Auchampach JA, Kreckler LM, Wan TC, Maas JE, van der Hoeven D, Gizewski $\mathrm{E}$, et al. Characterization of the A2B adenosine receptor from mouse, rabbit, and dog. The Journal of pharmacology and experimental therapeutics. 2009; 329: 2-13. doi:10.1124/jpet.108.148270.

4. Zheng M. Classification and Pathology of Lung Cancer. Surgical oncology clinics of North America. 2016; 25: 447-68. doi:10.1016/j.soc.2016.02.003.

5. Altan M, Chiang AC. Management of Small Cell Lung Cancer: Progress and Updates. Cancer journal. 2015; 21: 425-33. doi:10.1097/PPO.0000000000000148.

6. Domvri K, Darwiche K, Zarogoulidis P, Zarogoulidis K. Following the crumbs: from tissue samples, to pharmacogenomics, to NSCLC therapy. Translational lung cancer research. 2013; 2: 256-8. doi:10.3978/j.issn.2218-6751.2012.12.06.

7. Bajetta E, Catena L, Pusceddu S, Spada F, Iannacone C, Sarno I, et al. Everolimus in Combination with Octreotide LAR in First Line Setting for Patients with Neuroendocrine Tumors: A 5-Years Update. Neuroendocrinology. 2017. doi:10.1159/000479587.

8. Stinchcombe TE, Morris DE, Lee CB, Moore DT, Hayes DN, Halle JS, et al. Induction chemotherapy with carboplatin, irinotecan, and paclitaxel followed by high dose three-dimension conformal thoracic radiotherapy (74 Gy) with concurrent carboplatin, paclitaxel, and gefitinib in unresectable stage IIIA and stage IIIB non-small cell lung cancer. Journal of thoracic oncology : official publication of the International Association for the Study of Lung Cancer. 2008; 3: 250-7. doi:10.1097/JTO.0b013e3181653cf4.

9. Yoshida T, Yamada K, Azuma K, Kawahara A, Abe H, Hattori S, et al. Comparison of adverse events and efficacy between gefitinib and erlotinib in patients with non-small-cell lung cancer: a retrospective analysis. Medical oncology. 2013; 30: 349. doi:10.1007/s12032-012-0349-y.

10. Fajardo AM, Piazza GA, Tinsley HN. The role of cyclic nucleotide signaling pathways in cancer: targets for prevention and treatment. Cancers. 2014; 6: 436-58. doi:10.3390/cancers6010436.

11. Eskandari N, Mirmosayyeb O, Bordbari G, Bastan R, Yousefi Z, Andalib A. A short review on structure and role of cyclic-3',5'-adenosine monophosphate-specific phosphodiesterase 4 as a treatment tool. Journal of research in pharmacy practice. 2015; 4: 175-81. doi:10.4103/2279-042X.167043.

12. Piazza GA, Thompson WJ, Pamukcu R, Alila HW, Whitehead CM, Liu L, et al. Exisulind, a novel proapoptotic drug, inhibits rat urinary bladder tumorigenesis. Cancer research. 2001; 61: 3961-8.

13. Whitehead CM, Earle KA, Fetter J, Xu S, Hartman T, Chan DC, et al. Exisulind-induced apoptosis in a non-small cell lung cancer orthotopic lung tumor model augments docetaxel treatment and contributes to increased survival. Molecular cancer therapeutics. 2003; 2: 479-88.

14. Black KL, Yin D, Ong JM, Hu J, Konda BM, Wang X, et al. PDE5 inhibitors enhance tumor permeability and efficacy of chemotherapy in a rat brain tumor model. Brain research. 2008; 1230: 290-302. doi:10.1016/j.brainres.2008.06.122.

15. Catalano S, Campana A, Giordano C, Gyorffy B, Tarallo R, Rinaldi A, et al. Expression and Function of Phosphodiesterase Type 5 in Human Breast Cancer Cell Lines and Tissues: Implications for Targeted Therapy. Clinical cancer research : an official journal of the American Association for Cancer Research. 2016; 22: 2271-82. doi:10.1158/1078-0432.CCR-15-1900.

16. Porpodis K, Domvri K, Zarogoulidis P, Petridis D, Tsirgogianni K, Papaioannou A, et al. Roflumilast, a phosphodiesterase-4 inhibitor, induces phagocytic activity in Greek COPD patients. International journal of chronic obstructive pulmonary disease. 2015; 10: 1123-8. doi:10.2147/COPD.S83205.

17. Lahu G, Nassr N, Hunnemeyer A. Pharmacokinetic evaluation of roflumilast. Expert opinion on drug metabolism \& toxicology. 2011; 7: 1577-91. doi:10.1517/17425255.2011.632409.

18. Kelly KR, Mejia A, Suhasini A, Lin AP, Kuhn JG, Karnad A, et al. Safety and pharmacodynamics of the PDE4 inhibitor roflumilast in advanced B cell malignancies. Clinical cancer research : an official journal of the American Association for Cancer Research. 2016. doi:10.1158/1078-0432.CCR-16-1207.

19. Mei XL, Yang Y, Zhang YJ, Li Y, Zhao JM, Oiu JG, et al. Sildenafil inhibits the growth of human colorectal cancer in vitro and in vivo. American journal of cancer research. 2015; 5: 3311-24.

20. Sarfati M, Mateo V, Baudet S, Rubio M, Fernandez C, Davi F, et al. Sildenafil and vardenafil, types 5 and 6 phosphodiesterase inhibitors, induce caspase-dependent apoptosis of B-chronic lymphocytic leukemia cells. Blood. 2003; 101: 265-9. doi:10.1182/blood-2002-01-0075.

21. Eggen T, Sager G, Berg T, Nergaard B, Moe BT, Orbo A. Increased gene expression of the ABCC5 transporter without distinct changes in the expression of PDE5 in human cervical cancer cells during growth. Anticancer research. 2012; 32: 3055-61.

22. Bender AT, Beavo JA. Cyclic nucleotide phosphodiesterases: molecular regulation to clinical use. Pharmacological reviews. 2006; 58: 488-520. doi:10.1124/pr.58.3.5. 
23. Karami-Tehrani F, Moeinifard M, Aghaei M, Atri M. Evaluation of PDE5 and PDE9 expression in benign and malignant breast tumors. Archives of medical research. 2012; 43: 470-5. doi:10.1016/j.arcmed.2012.08.006.

24. Zhang X, Yan G, Ji J, Wu J, Sun X, Shen J, et al. PDE5 inhibitor promotes melanin synthesis through the PKG pathway in B16 melanoma cells. Journal of cellular biochemistry. 2012; 113: 2738-43. doi:10.1002/jcb.24147.

25. Nuhoglu Y, Nuhoglu C. Aminophylline for treating asthma and chronic obstructive pulmonary disease. Expert review of respiratory medicine. 2008; 2 : 305-13. doi:10.1586/17476348.2.3.305.

26. Mylonaki E, Manika K, Zarogoulidis P, Domvri K, Voutsas V, Zarogoulidis K, et al. In vivo synergistic cytogenetic effects of aminophylline on lymphocyte cultures from patients with lung cancer undergoing chemotherapy. Mutation research. 2012; 740: 1-5. doi:10.1016/j.mrfmmm.2012.10.002.

27. Ohta K, Fukuchi Y, Grouse L, Mizutani R, Rabe KF, Rennard SI, et al. A prospective clinical study of theophylline safety in 3810 elderly with asthma or COPD. Respiratory medicine. 2004; 98: 1016-24.

28. Hansel TT, Tennant RC, Tan AJ, Higgins LA, Neighbour H, Erin EM, et al. Theophylline: mechanism of action and use in asthma and chronic obstructive pulmonary disease. Drugs of today. 2004; 40: 55-69.

29. Corsano S, Scapicchi R, Strappaghetti G. Bronchodilator activity of theophylline derivatives substituted at the 7-position. Archiv der Pharmazie. 1994; 327: 631-5.

30. Gajewczyk L, Zejc A. [Synthesis of 1-N-aryloacetamidobutanol derivatives with anti-seizure effect]. Acta poloniae pharmaceutica. 1992; 49: 55-9.

31. Ruddarraju RR, Murugulla AC, Kotla R, Chandra Babu Tirumalasetty M, Wudayagiri R, Donthabakthuni S, et al. Design, synthesis, anticancer, antimicrobial activities and molecular docking studies of theophylline containing acetylenes and theophylline containing 1,2,3-triazoles with variant nucleoside derivatives. European journal of medicinal chemistry. 2016; 123: 379-96. doi:10.1016/j.ejmech.2016.07.024.

32. Makower D, Malik U, Novik Y, Wiernik PH. Therapeutic efficacy of theophylline in chronic lymphocytic leukemia. Medical oncology. 1999; 16: 69-71.

33. Mabed M, Aref S, Fouda M, El-Sharawy S. Chlorambucil plus theophylline vs chlorambucil alone as a front line therapy for B-cell chronic lymphatic leukemia. Leukemia \& lymphoma. 2004; 45: 2029-35. doi:10.1080/10428190410001714061.

34. Beninati S, Abbruzzese A, Cardinali M. Differences in the post-translational modification of proteins by polyamines between weakly and highly metastatic B16 melanoma cells. International journal of cancer. 1993; 53: 792-7.

35. Lentini A, Vidal-Vanaclocha F, Facchiano F, Caraglia M, Abbruzzese A, Beninati S. Theophylline administration markedly reduces hepatic and pulmonary implantation of B16-F10 melanoma cells in mice. Melanoma research. 2000; 10: 435-43.

36. Lentini A, Tabolacci C, Nardi A, Mattioli P, Provenzano B, Beninati S. Preclinical evaluation of the antineoplastic efficacy of 7-(2-hydroxyethyl)theophylline on melanoma cancer cells. Melanoma research. 2012; 22: 133-9. doi:10.1097/CMR.0b013e328350d228.

37. Bertram JS, Janik P. Establishment of a cloned line of Lewis Lung Carcinoma cells adapted to cell culture. Cancer letters. 1980; 11: 63-73.

38. Galluzzi L, Senovilla L, Vitale I, Michels J, Martins I, Kepp O, et al. Molecular mechanisms of cisplatin resistance. Oncogene. 2012; 31: 1869-83. doi:10.1038/onc. 2011.384

39. Fichtinger-Schepman AM, van der Veer JL, den Hartog JH, Lohman $\mathrm{PH}$, Reedijk J. Adducts of the antitumor drug cis-diamminedichloroplatinum(II) with DNA: formation, identification, and quantitation. Biochemistry. 1985; 24: $707-13$

40. Sorenson CM, Eastman A. Influence of cis-diamminedichloroplatinum(II) on DNA synthesis and cell cycle progression in excision repair proficient and deficient Chinese hamster ovary cells. Cancer research. 1988; 48: 6703-7.

41. Vaisman A, Varchenko M, Said I, Chaney SG. Cell cycle changes associated with formation of Pt-DNA adducts in human ovarian carcinoma cells with different cisplatin sensitivity. Cytometry. 1997; 27: 54-64.

42. Henkels KM, Turchi JJ. Induction of apoptosis in cisplatin-sensitive and -resistant human ovarian cancer cell lines. Cancer research. 1997: 57: 4488-92.

43. Yoshida Y, Hosokawa K, Dantes A, Tajima K, Kotsuji F, Amsterdam A. Theophylline and cisplatin synergize in down regulation of BCL-2 induction of apoptosis in human granulosa cells transformed by a mutated p53 (p53 val135) and Ha-ras oncogene. International journal of oncology. 2000; 17: 227-35.

44. Corbin JD, Francis SH. Cyclic GMP phosphodiesterase-5: target of sildenafil. The Journal of biological chemistry. 1999; 274: 13729-32.

45. Corbin JD, Beasley A, Blount MA, Francis SH. Vardenafil: structural basis for higher potency over sildenafil in inhibiting cGMP-specific phosphodiesterase-5 (PDE5). Neurochemistry international. 2004; 45: 859-63. doi:10.1016/j.neuint.2004.03.016.

46. Li Q, Shu Y. Pharmacological modulation of cytotoxicity and cellular uptake of anti-cancer drugs by PDE5 inhibitors in lung cancer cells. Pharmaceutical research. 2014; 31: 86-96. doi:10.1007/s11095-013-1134-0.

47. Zhu B, Strada SJ. The novel functions of cGMP-specific phosphodiesterase 5 and its inhibitors in carcinoma cells and pulmonary/cardiovascular vessels. Current topics in medicinal chemistry. 2007; 7: 437-54.

48. Thompson WJ, Piazza GA, Li H, Liu L, Fetter J, Zhu B, et al. Exisulind induction of apoptosis involves guanosine $3^{\prime}, 5^{\prime}$-cyclic monophosphate phosphodiesterase inhibition, protein kinase G activation, and attenuated beta-catenin. Cancer research. 2000; 60: 3338-42

49. Serafini P, Meckel K, Kelso M, Noonan K, Califano J, Koch W, et al. Phosphodiesterase- 5 inhibition augments endogenous antitumor immunity by reducing myeloid-derived suppressor cell function. The Journal of experimental medicine. 2006; 203: 2691-702. doi:10.1084/jem.20061104.

50. Meyer C, Sevko A, Ramacher M, Bazhin AV, Falk CS, Osen W, et al. Chronic inflammation promotes myeloid-derived suppressor cell activation blocking antitumor immunity in transgenic mouse melanoma model. Proceedings of the National Academy of Sciences of the United States of America. 2011; 108: 17111-6. doi:10.1073/pnas.1108121108.

51. El-Naa MM, Othman M, Younes S. Sildenafil potentiates the antitumor activity of cisplatin by induction of apoptosis and inhibition of proliferation and angiogenesis. Drug design, development and therapy. 2016; 10: 3661-72. doi:10.2147/DDDT.S107490.

52. Das A, Durrant D, Mitchell C, Mayton E, Hoke NN, Salloum FN, et al. Sildenafil increases chemotherapeutic efficacy of doxorubicin in prostate cancer and ameliorates cardiac dysfunction. Proceedings of the National Academy of Sciences of the United States of America. 2010; 107: 18202-7. doi:10.1073/pnas.1006965107.

53. Tinsley HN, Gary BD, Keeton AB, Zhang W, Abadi AH, Reynolds RC, et al. Sulindac sulfide selectively inhibits growth and induces apoptosis of human breast tumor cells by phosphodiesterase 5 inhibition, elevation of cyclic GMP, and activation of protein kinase G. Molecular cancer therapeutics. 2009; 8: 3331-40. doi:10.1158/1535-7163.MCT-09-0758.

54. Zhu B, Vemavarapu L, Thompson WJ, Strada SJ. Suppression of cyclic GMP-specific phosphodiesterase 5 promotes apoptosis and inhibits growth in HT29 cells. Journal of cellular biochemistry. 2005; 94: 336-50. doi:10.1002/jcb.20286.

55. Booth L, Roberts JL, Cruickshanks N, Tavallai S, Webb T, Samuel P, et al. PDE5 inhibitors enhance celecoxib killing in multiple tumor types. Journal of cellular physiology. 2015; 230: 1115-27. doi:10.1002/jcp.24843.

56. Di X, Gennings C, Bear HD, Graham LJ, Sheth CM, White KL, Jr., et al. Influence of the phosphodiesterase- 5 inhibitor, sildenafil, on sensitivity to chemotherapy in breast tumor cells. Breast cancer research and treatment. 2010; 124: 349-60. doi:10.1007/s10549-010-0765-7.

57. Roberts JL, Booth L, Conley A, Cruickshanks N, Malkin M, Kukreja RC, et al. PDE5 inhibitors enhance the lethality of standard of care chemotherapy in pediatric CNS tumor cells. Cancer biology \& therapy. 2014; 15: 758-67. doi: $10.4161 / \mathrm{cbt} .28553$.

58. Chen JJ, Sun YL, Tiwari AK, Xiao ZJ, Sodani K, Yang DH, et al. PDE5 inhibitors, sildenafil and vardenafil, reverse multidrug resistance by inhibiting the efflux function of multidrug resistance protein 7 (ATP-binding Cassette C10) transporter. Cancer science. 2012; 103: 1531-7. doi:10.1111/j.1349-7006.2012.02328.x.

59. Milligan PA, Marshall SF, Karlsson MO. A population pharmacokinetic analysis of sildenafil citrate in patients with erectile dysfunction. British journal of clinical pharmacology. 2002; 53 Suppl 1: 45S-52S.

60. Kanjanawart S, Gaysonsiri D, Tangsucharit P, Vannaprasaht S, Phunikhom K, Kaewkamson T, et al. Comparative bioavailability of two sildenafil tablet formulations after single-dose administration in healthy Thai male volunteers. International journal of clinical pharmacology and therapeutics. 2011; 49: 525-30.

61. Das A, Durrant D, Mitchell C, Dent P, Batra SK, Kukreja RC. Sildenafil (Viagra) sensitizes prostate cancer cells to doxorubicin-mediated apoptosis through CD95. Oncotarget. 2016; 7: 4399-413. doi:10.18632/oncotarget.6749.

62. Shi Z, Tiwari AK, Patel AS, Fu LW, Chen ZS. Roles of sildenafil in enhancing drug sensitivity in cancer. Cancer research. 2011; 71: 3735-8. doi:10.1158/0008-5472.CAN-11-0375.

63. Shi Z, Tiwari AK, Shukla S, Robey RW, Singh S, Kim IW, et al. Sildenafil reverses $\mathrm{ABCB} 1$ - and $\mathrm{ABCG} 2-$ mediated chemotherapeutic drug resistance. Cancer research 2011: 71: 3029-41 doi:10.1158/0008-5472 CAN-10-3820.

64. Lin F, Hoogendijk L, Buil L, Beijnen JH, van Tellingen O. Sildenafil is not a useful modulator of $\mathrm{ABCB} 1$ and ABCG2 mediated drug resistance in vivo. European journal of cancer. 2013; 49: 2059-64. doi:10.1016/j.ejca.2012.12.028

65. Li WQ, Qureshi AA, Robinson KC, Han J. Sildenafil use and increased risk of incident melanoma in US men: a prospective cohort study. JAMA internal medicine. 2014; 174: 964-70. doi:10.1001/jamainternmed.2014.594.

66. Loeb S, Folkvaljon $\mathrm{Y}$, Lambe M, Robinson D, Garmo H, Ingvar C, et al. Use of Phosphodiesterase Type 5 Inhibitors for Erectile Dysfunction and Risk of Malignant Melanoma. Jama. 2015; 313: 2449-55. doi:10.1001/jama.2015.6604.

67. Lian $\mathrm{Y}$, Yin $\mathrm{H}$, Pollak $\mathrm{MN}$, Carrier $\mathrm{S}$, Platt $\mathrm{RW}$, Suissa $\mathrm{S}$, et al. Phosphodiesterase Type 5 Inhibitors and the Risk of Melanoma Skin Cancer. European urology. 2016; 70: 808-15. doi:10.1016/j.eururo.2016.04.035.

68. Matthews A, Langan SM, Douglas IJ, Smeeth L, Bhaskaran K. Phosphodiesterase Type 5 Inhibitors and Risk of Malignant Melanoma: Matched Cohort Study Using Primary Care Data from the UK Clinical Practice Research Datalink. PLoS medicine. 2016; 13: e1002037. doi:10.1371/journal.pmed.1002037.

69. Dhayade S, Kaesler S, Sinnberg T, Dobrowinski H, Peters S, Naumann U, et al. Sildenafil Potentiates a cGMP-Dependent Pathway to Promote Melanoma Growth. Cell reports. 2016; 14: 2599-610. doi:10.1016/j.celrep.2016.02.028.

70. Pottegard A, Schmidt SA, Olesen AB, Achacoso N, Van Den Eeden SK, Hallas $\mathrm{J}$, et al. Use of sildenafil or other phosphodiesterase inhibitors and risk of 
melanoma. British journal of cancer. 2016; 115: 895-900. doi:10.1038/bjc.2016.248.

71. Hirsh L, Dantes A, Suh BS, Yoshida Y, Hosokawa K, Tajima K, et al. Phosphodiesterase inhibitors as anti-cancer drugs. Biochemical pharmacology. 2004; 68: 981-8. doi:10.1016/j.bcp.2004.05.026.

72. Karademir LD, Dogruel F, Kocyigit I, Yazici C, Unal A, Sipahioglu MH, et al. The efficacy of theophylline in preventing cisplatin-related nephrotoxicity in patients with cancer. Renal failure. 2016; 38: 806-14. doi:10.3109/0886022X.2016.1163154.

73. Merimsky O, Hirsh L, Dantes A, Land-Bracha A, Suh BS, Amsterdam A. Induction of apoptosis in non-small lung carcinoma cell line (H1299) by combination of anti-asthma drugs with gemcitabine and cisplatin. International journal of oncology. 2005; 26: 475-82.

74. Lentini A, Tabolacci C, Mattioli P, Provenzano B, Beninati S. Antitumor activity of theophylline in combination with Paclitaxel: a preclinical study on melanoma experimental lung metastasis. Cancer biotherapy \& radiopharmaceuticals. 2010; 25: 497-503. doi:10.1089/cbr.2010.0787.

75. Smith PG, Wang F, Wilkinson KN, Savage KJ, Klein U, Neuberg DS, et al. The phosphodiesterase PDE4B limits cAMP-associated PI3K/AKT-dependent apoptosis in diffuse large B-cell lymphoma. Blood. 2005; 105: 308-16. doi:10.1182/blood-2004-01-0240.

76. Kim SW, Rai D, McKeller MR, Aguiar RC. Rational combined targeting of phosphodiesterase 4B and SYK in DLBCL. Blood. 2009; 113: 6153-60. doi:10.1182/blood-2009-02-206128.

77. Suhasini AN, Wang L, Holder KN, Lin AP, Bhatnagar H, Kim SW, et al. A phosphodiesterase 4B-dependent interplay between tumor cells and the microenvironment regulates angiogenesis in B-cell lymphoma. Leukemia. 2016; 30: 617-26. doi:10.1038/leu.2015.302.

78. Kim SW, Rai D, Aguiar RC. Gene set enrichment analysis unveils the mechanism for the phosphodiesterase $4 \mathrm{~B}$ control of glucocorticoid response in B-cell lymphoma. Clinical cancer research : an official journal of the American Association for Cancer Research. 2011; 17: 6723-32. doi:10.1158/1078-0432.CCR-11-0770. 